\title{
Esoterismo ocidental em terras latinoamericanas: notas sobre o Movimento Gnóstico de Samael Aun Weor
}

\section{Occidental Esotericism in Latin American lands: notes about the Gnostic Movement of Samael Aun Weor}

\author{
Marcelo Leandro de Campos \\ Historiador, com Licenciatura/Bacharelado em História pela PUC Campinas; Mestre em Ciências da \\ Religião pela PUC Campinas; Master Coach filiado à Sociedade Latinoamericana de Coaching; Professor \\ de Educação Financeira e Coaching na EGDS-Campinas. Contato: mlcampos 2005@hotmail.com
}

\begin{abstract}
Ana Rosa Cloclet da Silva
Docente da Faculdade de História da PUC-Campinas e do Programa de Pós-Graduação Stricto Sensu em Ciências da Religião, pela mesma Universidade. É doutora em História pela Universidade Estadual de Campinas (2000) e pós-doutora na mesma área pela USP (2007). Possui graduação em Ciências Econômicas pela Universidade Estadual de Campinas (1993) e mestrado em História pela Universidade Estadual de Campinas (1996). Contato: anacloclet@gmail.com
\end{abstract}

DOI: http://dx.doi.org/10.15517/rehmlac.v8i1.24283

Fecha de recibido: 3 de enero de 2016 - Fecha de aceptación: 2 de marzo de 2016

Palavras-chave

Neognosticismo, esoterismo na América Latina, magia sexual, Gurdjieff, Antiga Fraternidade Rosacruz

Keywords

Neo-Gnosticism, esotericism in Latin America, sexual magic, Gurdjieff, Ancient Rosicrucian Fellowship

\section{Resumo}

Este artigo apresenta a figura do esoterista colombiano Samael Aun Weor em dois contextos: o primeiro, inserido num quadro mais geral de chegada das ideias esotéricas europeias à América Latina e de sua reinterpretação a partir de peculiaridades endógenas; no seu caso específico, nos debruçamos sobre suas contribuições doutrinárias a respeito do magismo sexual; o segundo, analisando as dinâmicas fundamentais em torno da qual se constitui o gnosticismo samaeliano; neste caso dedicamos nossa atenção à progressiva influência que o pensamento de Gurdjieff/Ouspensky exercem sobre a obra de Samael e suas implicações no campo institucional, principalmente após sua morte.

\begin{abstract}
This article presents the Colombian esoteric Samael Aun Weor in two contexts: first, inserted in a more general framework arrival of European esoteric ideas to Latin America and its reinterpretation from endogenous peculiarities; in this particular case, we worked through on his doctrinal contributions regarding sexual magic; second, we analyzed the fundamental dynamics which constitutes the Samael's Gnosticism. In this case we concentrated on the progressive influence Gurdjieff / Ouspensky's thought has on Samael's work and its implications in the institutional field, especially after his death.
\end{abstract}




\section{Introdução}

Nosso objetivo, neste artigo, é oferecer uma breve análise sobre uma versão do gnosticismo moderno, surgida na Colômbia em meados do século, e seu fundador, conhecido no milieu esotérico como Samael Aun Weor. As novas espiritualidades de cunho esotérico são normalmente estudadas a partir de uma aproximação antropológica, vistas sob o prisma de um "conceito guarda-chuva" - o de Novos Movimentos Religiosos (NMR) -, assim considerado por pretender abarcar quase tudo que surge no horizonte espiritualista e religioso nos últimos cinquenta anos, pelo menos, e como parte de um fenômeno, também de difícil delimitação conceitual, normalmente conhecido como Movimento Nova Era (New Age).

No presente artigo, nossa contribuição vai em outra direção. Especificamente, o movimento fundado pelo esoterista colombiano Samael Aun Weor será abordado à luz do conceito de "secularização do esoterismo", proposto pelo historiador Wouter Hanegraaff, a partir da qual pretendemos contribuir com o debate interdisciplinar que articula o campo da História Cultural, da História das Religiões e da recente História do Esoterismo Ocidental. A nosso ver, tal conceito revela-se operacional na compreensão das relações reversivas e influências mútuas que pautam, de um lado, a construção da moderna cultura ocidental e seus paradigmas de racionalidade e ciência empírica; de outro, a constituição de uma tradição esotérica que busca harmonizar estes paradigmas com uma concepção fortemente "encantada" do universo, e dos mútuos processos de apropriação/reinterpretação envolvidos nesta dinâmica. De modo mais específico, tal abordagem dialoga com uma discussão recorrente no campo das Ciências da Religião, que busca compreender as transformações que ocorrem no campo religioso ocidental frente à nova sociedade secularizada. Nossa contribuição, neste sentido, conduz a uma aproximação histórico-cultural sobre o tema, inserindo Samael, sua doutrina, práticas e formas de institucionalização nos contextos de formação do moderno ocultismo europeu e de sua chegada à América Latina, bem como seu papel na consolidação de uma sociedade secularizada, que se manteve profundamente religiosa e herdeira de uma tradição que esteve no bojo da própria modernidade ocidental.

Samael Aun Weor é o pseudônimo do esoterista colombiano Victor Manuel Gomez (1917-1977). Nascido numa tradicional família de classe média em Bogotá, Samael segue uma trajetória muito comum a outros líderes esotéricos: uma infância católica, o interesse sobre temas sobrenaturais despertado pela literatura espírita, no inicio da adolescência e a primeira militância no esoterismo num centro da Sociedade Teosófica, na juventude. Em 1936 Samael filiou-se à loja colombiana da Fraternitas Rosicruciana Antiqua - a Fraternidade Rosacruz Antiga (FRA) -, fundada uma década antes pelo respeitado esoterista alemão Arnold Krum-Heller.

Entre os rosacruzes Samael tomou contato com dois importantes elementos que se tornariam centrais em sua doutrina: as reinterpretações modernas do pensamento e das práticas dos gnósticos da Antiguidade Tardia; e as práticas de Magia Sexual, releituras ocidentais de técnicas tântricas oriundas da Índia. Neste sentido, conforme 
veremos, Samael estabeleceu o diálogo com uma concepção de esoterismo cristão muito comum nas correntes esotérico-espiritualistas de sua época: a de que os o grupos gnósticos da antiguidade seriam os detentores de uma série de ensinamentos mágicos ensinados por Jesus Cristo que, segundo tal imaginário, era concebido como uma espécie de "mago dos magos".

$\mathrm{O}$ interesse por pergaminhos gnósticos inaugura o Hermetismo renascentista como descreve brilhantemente Frances Yates em sua obra ${ }^{1}$ e, a partir do século XIX, dá origem às igrejas gnósticas, seitas de caráter esotérico que se acreditam detentoras das chaves e práticas mágicas do cristianismo primitivo, conforme estudado por Massimo Introvigne ${ }^{2}$. Para Samael, no entanto, as chaves mágicas dos primitivos gnósticos giram em torno de práticas tântricas, ideia esta já sugerida na obra de Krum-Heller. Para Samael, no entanto, ela adquire uma centralidade inédita: para ele, este conjunto de práticas constitui a própria essência dos ensinamentos cristãos.

Esse desenvolvimento não é estranho ao cenário esotérico de sua época. Há, de fato, no cenário ocultista e rosacruz, autores ensinando técnicas de magia sexual desde a segunda metade do século XIX, sendo o mais conhecido deles o mago inglês Aleister Crowley (1875-1947). Tais ideias, contudo, são pouco disseminadas no milieu esotérico, sobretudo na comunidade mais numerosa, a dos teósofos.

O fato é que as apropriações de Samael sobre a obra de Krum-Heller, fortemente impregnadas de uma visão milenarista de fim iminente dos tempos e da necessidade de uma "purificação" das instituições esotéricas existentes, encontraram pouco eco nas fileiras rosacruzes. Por isso, Samael afastou-se inicialmente dos rosacruzes, empreendendo uma longa peregrinação pelo interior da Colômbia, durante a qual amadureceu suas ideias e, supostamente, atingiu a "iluminação" ${ }^{3}$. Com a morte de Krum-Heller, em 1949, ele organizou sua própria escola esotérica, o Movimento Gnóstico, e iniciou sua cruzada de disseminação das práticas de Magia Sexual. Fez construir um templo esotérico em plena selva colombiana - o Summum Supremum Sanctuarium - e, em 1954, anunciou haver atingido o estado de "cristificação"; em outras palavras, havia se convertido numa encarnação de Cristo.

As ideias de Samael produziram violentas reações por parte da Igreja católica colombiana, que terminaram por obrigá-lo a se mudar com sua família para o México, no ano seguinte. No ambiente secularizado mexicano, Samael encontrou a liberdade necessária para escrever seus livros e estruturar internacionalmente sua escola esotérica, que logo se espalhou por todo o continente.

Com sua morte, em 1977, seus principais discípulos e familiares disputaram o controle de suas instituições, que experimentaram, desde então, um crescente processo de fragmentação, que também será objeto de análise neste artigo. Ao mesmo tempo, a gnose samaeliana passou a ter uma crescente presença na Europa e, mais recentemente, no Leste Europeu e na África.

\footnotetext{
${ }^{1}$ Frances Yates, Giordano Bruno e a Tradição Hermética (São Paulo: Circulo do Livro, 1991).

${ }^{2}$ Massimo Introvigne, Il Ritorno dell Gnosticismo (Varese: SugarCo., 1993).

${ }^{3}$ Aqui entendida no sentido de contato direto com a realidade, com a alma do universo.
} 
$\mathrm{O}$ artigo inicia com uma exposição panorâmica da chegada e difusão das correntes esotéricas na América Latina, chamando a atenção para a intensa adaptação que o esoterismo aí operou em relação ao imaginário iluminista dominante, aspecto fundamental para se compreender o sucesso de sua rápida disseminação nos espaços urbanos latinoamericanos. Em seguida, nossa análise se concentra nas dinâmicas históricas que assistem à difusão do esoterismo na Colômbia e que culminarão na fundação do Movimento Gnóstico de Samael Aun Weor.

\section{Presença Esotérica na América Latina}

A chegada de ideias mágico-esotéricas à América Latina e sua institucionalização não pode ser entendida sem levar em conta o contexto maior em que tal fenômeno esteve inserido: o da "longa duração" da história da magia no ocidente, um importante capítulo em que as correntes mágicas interagem e se apropriam de elementos dos novos paradigmas do pensamento moderno, ou seja, a razão e a ciência empírica. Da mesma forma, a proliferação do gnosticismo moderno e de práticas de magia sexual na América Latina, no início da segunda metade do século XX, é parte integrante de pelo menos três dinâmicas: primeiro, a história da chegada do esoterismo europeu à América Latina e de sua transformação a partir das releituras endógenas, fortemente influenciadas pelo catolicismo popular, e do surgimento de novas formas institucionais; segundo, a história das interpretações esotéricas sobre a sexualidade e seu papel na construção das concepções ocidentais sobre o tema; terceiro, o próprio contexto político e social em que se desenvolve o esoterismo e suas mútuas relações reversivas, sobretudo de caráter cultural.

Quanto ao primeiro ponto, vale frisar que o esoterismo que chega à América Latina, de maneira mais pronunciada a partir da segunda metade do século XIX, tem três ingredientes principais, que misturados em várias combinações dariam origem a uma vasta gama de elaborações doutrinárias. De um lado, as concepções teosóficas fortemente influenciadas pelo iluminismo e por ideias de evolução social e de uma "ciência esotérica", capaz de explicar os fenômenos sobrenaturais; de outro, um ocultismo rosacrucianista centrado num elaborado ritualismo mágico, que permitiria movimentar forças sobrenaturais e estabelecer contatos com seres extramundanos; por fim, um interesse intenso por práticas e elementos da religiosidade oriental, reinterpretados à luz do imaginário iluminista da Belle Epoque e transformados em exercícios que proporcionariam diversos tipos de benefícios à saúde, à regeneração do corpo físico e ao desenvolvimento de capacidades psíquicas.

Como têm demonstrado trabalhos mais recentes sobre o tema, as correntes esotéricas, em franca expansão no final do século XIX e início do XX, embora fortemente impregnadas de um discurso crítico em relação ao materialismo da sociedade moderna, têm a base de suas doutrinas elaboradas a partir de valores modernos, numa evidente apropriação do iluminismo vigente, como é o caso da apologia das ciências empíricas. Por conta disso, o esoterismo, via de regra, se 
institucionaliza em sociedades que vivem um franco processo de secularização, e as próprias sociedades esotéricas, em sua maioria, são agentes ativos deste processo, como fica evidente quando observamos, por exemplo, a ação das lojas teosóficas no cenário político e social da América Central no início do século XX. Neste sentido, é possível concordar que, embora um dos desdobramentos notórios da secularização tenha sido a constituição de Estados laicos, a religião e as concepções encantadas de mundo, continuaram utilizando-se dos seus próprios resultados para manter-se influente na esfera pública, situação que, segundo Berger, comprova-se pela "progressiva burocratização das instituições religiosas",

A despeito da flagrante lacuna de estudos acerca da chegada e disseminação das ideias esotéricas na América Latina, acreditamos que esse modelo estrutural determina, em grande medida, o crescimento do esoterismo moderno ${ }^{5}$ nas Américas, onde ele se institucionaliza a partir dos Estados Unidos protestante, desde a segunda metade do XIX. Este país irá se constituir num polo natural de irradiação do esoterismo para seus vizinhos centroamericanos e para o México, onde, a despeito do predomínio do catolicismo, também ocorre um rápido processo de secularização, sobretudo a partir da revolução de 1910 .

Há ainda duas dinâmicas de disseminação importantes, que não podem ser ignoradas. Uma primeira, em que o esoterismo chega diretamente da Europa, trazido por imigrantes que se mudam para o Novo Mundo e estabelecem pequenos grupos, normalmente dentro da própria comunidade de imigrantes locais, favorecidos pela comunicação com suas instituições de origem, com as quais mantém filiação. É o caso, por exemplo, de discípulos de Papus (Dr. Encausse), que viveram na Argentina e no Chile $^{6}$. A segunda é fruto de iniciativas endógenas, normalmente oriundas ou ligadas a círculos maçônicos, ávidos consumidores da literatura europeia sobre o tema - tida como ícone da modernidade almejada pelas elites do continente - e que constituem um

\footnotetext{
${ }^{4}$ Peter Berger, O Dossel Sagrado. (São Paulo: Paulinas, 1985), 151.

${ }^{5}$ Como bem salienta Juan Pablo Bubello, no caso da América Latina, é preciso distinguir entre um esoterismo tradicional - resultado das múltiplas composições entre o magismo indígena e o magismo popular trazido pelos conquistadores europeus, desde o início da colonização, que adquire nuances específicas no meio rural e urbano -, do esoterismo moderno - trazido pelas ondas de imigrantes europeus do século XIX. Embora ambos pertençam ao mesmo universo simbólico, as práticas e representações do segundo se distinguem das do primeiro pelo nível de erudição (Juan Pablo Bubello. Difusión del esoterismo europeo-occidental en el Nuevo Continente (siglos XVI-XX): la conformación de un "campo esotérico" en la Argentina del siglo XX, en Estudios sobre La Historia del Esoterismo Occidental en America Latina: enfoques, aportes, problemas y debates (no prelo), Bubello, Chaves, Junior eds., 5-6.

${ }^{6}$ Arturo Clement e o médico francês Henri Girgois, que vão iniciar Krum-Heller no ocultismo (H. S. Tsadhe, Krum-Heller, El Rosa Cruz. Fraternitas Rosicruciana Antiqua de Venezuela, ano n/d, 16-18). Girgois era martinista e membro do Groupe Independance de Études Esoteriques, de Papus, e atuou como médico do exército argentino na década de 1879; seu contato com os índios araucanos da região dos pampas o levou a escrever um livro onde descreve o conhecimento esotérico presente na mitologia dos incas e dos índios argentinos, El oculto entre los aborígenes de La America Del Sud. Ele revela um assombro particular com os conhecimentos medicinais dos indígenas, citando a cura de um soldado sifilítico com plantas, e faz um relato antropológico da iniciação da bruxa dos pampas, a machi $(\mathrm{H}$. Girgois, El Oculto entre los aborígenes de La America Del Sud (Buenos Aires: editor n/d, 1901), 155). Sua linguagem apologética, da pureza do indígena em contraste com a barbárie da civilização européia, é recorrente na obra de Krum-Heller.
} 
dos principais ambientes em que se discute e incentiva o processo de secularização da sociedade, articuladamente aos modelos nacionais ${ }^{7}$. Deves Valdes e Melgar Bao destacam o dinamismo que o ambiente esotérico e espiritualista latinoamericano experimenta diante das facilidades de acesso aos livros publicados em Nova Iorque e na Europa, desde o fim da I Guerra Mundial ${ }^{8}$. E, via de regra, as distintas dinâmicas acabam se tornando complementares: os esoteristas vindos da Europa são muitas vezes acolhidos pelos círculos maçônicos locais que, por sua vez, mantêm algum nível de relação com seus congêneres e grupos esotéricos nos Estados Unidos ${ }^{9}$.

Especificamente, acompanhando a expansão da teosofia e do rosacrucianismo pela América Latina, somos levados a destacar o papel dos Estados Unidos e do México, como verdadeiros trampolins de sua expansão institucional pelo restante do continente. Assim, temos como exemplo, a Fraternitas Rosace Crucis (FRC), fundada em San Francisco, em 1861, por Paschal Beverly Randolph (1825-1875); a Sociedade Teosófica $^{10}$ (ST) nascida em Nova Iorque, em 1875; nessa mesma cidade surge, em 1915, uma das maiores instituições esotéricas da modernidade, a Antiga e Mística Ordem Rosacruz (AMORC), fundada por Harvey Spencer Lewis (1883-1939). Da mesma forma, Max Heindel (1865-1919), outro pioneiro do esoterismo americano, após a habitual passagem pela Teosofia, fundou em 1909, a Fraternidade Rosacruz, em Oceanside, Califórnia; lojas rosacruzes já podiam ser encontradas em Porto Rico, em 1916, e no México em 1919. A Sociedade Teosófica, como sempre, chegou antes ${ }^{11}$ : já estava presente em Cuba, em 1905 e, no ano seguinte, em Porto Rico e no México ${ }^{12}$.

Como espaço natural, as escolas esotéricas adotam os grandes centros urbanos ${ }^{13}$, onde ocorre intensa circulação de ideias e se constitui, com relativa liberdade, um

\footnotetext{
${ }^{7}$ Lempiére Guerra, Los espacios públicos em Iberoamérica, Ambiguidades y Problemas. Siglos XVIII e XIX (México: CEMCA/FCE, 1998).

${ }^{8}$ Deves Valdes e Melgar Rao, "Redes teosóficas y pensadores (políticos) latinoamericanos 1910-1930", Cuadernos Americanos 78 (1999): 137-152.

9 Tal endogeneidade e circulação das ideias esotéricas seria uma característica das escolas latinoamericanas. Embora também estivessem presentes nas mais importantes metrópoles asiáticas e africanas das colônias européias, aí permaneceram majoritariamente restritas às comunidades de imigrantes, principalmente na Índia.

10 Goodrick-Clarke assim resume o pensamento teosófico: “A Teosofia é uma reação (ao discurso científico); longe de desacreditar a ciência, no entanto, os teósofos propõem uma adaptação das ideias científicas contemporâneas para corroborar a ideia de evolução espiritual através de inúmeros mundos e épocas, restaurando a dignidade e o propósito da vida humana dentro de um contexto cósmico. A mitologia greco-romana e egípcia e os elementos tradicionais da maçonaria e do rosacrucianismo foram combinados com a fascinação romântica com o oriente, assimilando elementos do budismo e do vedanta. A ideia renascentista de prisca theologia foi ambientada num cenário idealista de adeptos imortais vivendo nos Himalaias" (Nicholas Goodrick-Clarke, The Western Esoteric Tradition: a historical introduction (Oxford: OxfordUniversity Press, 2008), 30.

${ }^{11}$ Também é uma das precursoras do esoterismo no Brasil; há noticias de um importante centro teosófico no Rio de Janeiro, em 1898; segundo Deves Valdes e Melgar Bao, a seção brasileira é a pioneira na América do Sul (Valdes e Bao, "Redes teosóficas", 142).

${ }^{12}$ L. Armais Tirado, Nuestra historia en Puerto Rico. Data n/d; Victor H. Vallejo. Passado, Presente y Futuro de la Francmasonería (2001).

${ }^{13} \mathrm{Ou}$, pelo menos, essa é a dinâmica que temos melhor documentada. Ainda há distintos contextos históricos aguardando análise, como é o caso da rápida disseminação do espiritismo pelo interior da
} 
espaço de pluralidade religiosa. Como demonstrado na obra clássica do historiador argentino José Luis Romero, as cidades latinoamericanas constituem, naquele momento, centros de intensa fermentação cultural, política e social, oferecendo valiosas chavesinterpretativas para "um fenômeno que esteve à mercê tanto dos impactos externos quanto das ideias nelas produzidas", resultado de "importações sucessivas", mas também de peculiaridades de cada estrutura urbana ${ }^{14}$. Neste espaço, as instituições esotéricas iriam se desenvolver, primeiramente, nos círculos maçônicos, constituídos em sua maioria por comerciantes, profissionais liberais, funcionários públicos, militares e acadêmicos.

É importante esclarecer que essa onda esotérica que chega à América, no início do século XX, está fortemente associada à disseminação do espiritualismo ${ }^{15}$ e do espiritismo, que em seu conjunto são consideradas, então, como a vanguarda do pensamento moderno, do próprio iluminismo ${ }^{16}$ e sua ilusão positivista de progresso indefinido ${ }^{17}$. Segundo Deves Valdes e Melgar Bao, a influência artístico-literária e política do esoterismo latinoamericano, nesse momento, constitui "uma atitude cultural no marco dos grandes embates da modernidade, coincidindo com as coordenadas da segunda revolução industrial"18; a agenda destes grupos está impregnada da defesa de valores democráticos, da universalização da educação, do racionalismo, da igualdade de gênero, etc. Distinguem-se, em relação a correntes como o positivismo, pela sua crítica intransigente ao materialismo. No plano social, porém, fazem parecer tímidas a maioria das correntes liberais em ascensão no continente ${ }^{19}$, e constituem, em grande medida, o ponto de partida para a constituição de toda uma rede de pensamento político na América Latina ${ }^{20}$.

A professora María Elena Casaús chega a sugerir que a emergência das correntes nacionalistas e a própria reformulação da identidade coletiva, no sentido de construir uma identidade nacional e Centro-americana, esteve intimamente ligada à disseminação de ideias promovidas por círculos espiritualistas e espiritistas, assim como da própria teosofia como corrente filosófica. ${ }^{21} \mathrm{Da}$ mesma forma, Wunderich destaca que o

Colômbia, no início do século XX, sugerindo uma rápida aceitação pela população local por conta de similaridades com as práticas e crenças de origem indígena, fortemente disseminadas.

${ }^{14}$ José Luiz Romero, A s cidades e as idéias (Rio de Janeiro: Ed. UFRJ, 2004), 7.

15 Que, na ótica do escritor uruguaio José Rodó, que em 1900 publica Ariel, constituiria a essência identitária da América do Sul, em contraposição ao "utilitarismo" da América anglo-saxônica (Carlos Trillo, Recuentos Y Revalorizaciones al Mensage del Ariel de Rodó Cién Años Despues (Mexicali: UABC, 2000), 83-84.

${ }^{16}$ Marta Elena Casaús, "La creación de nuevos espacios públicos en Centroamérica a principios del siglo XX: La influencia de redes teosóficas en la opinión pública centroamericana", Revista Universum 17 (2002): 297-332.

${ }^{17}$ Bubello, "Difusión del esoterismo europeo-occidental en el Nuevo Continente (siglos XVI-XX): la conformación de un "campo esotérico" en la Argentina del siglo XX", en Estudios sobre La Historia del Esoterismo Occidental en America Latina, 26.

${ }^{18}$ Deves e Rao, "Redes teosóficas", 139.

${ }^{19}$ Deves e Rao, El pensamiento latinoamericano em el siglo XX, entre la modernizacón y la identidad. Del Ariel de Rodó a La CEPAL (1900-1950) (Buenos Aires: Biblos, 2000), 41.

${ }^{20}$ Deves e Rao, "Redes teosóficas", 138.

${ }^{21}$ Casaús, "La creación de nuevos espacios públicos en Centroamérica”, 300. 
interesse pela teosofia "marcou toda uma geração de poetas e intelectuais centroamericanos" 22 . Esse "espiritualismo nacionalista", de forte acento teosóficooriental, desempenhou importante papel político e intelectual na região ${ }^{23}$, influenciando e contando com a militância de figuras como o General Madero ${ }^{24}$, no México, Alberto Masferrer, em El Salvador, o presidente salvadorenho Maximiliano Hernández ${ }^{25}$, o revolucionário Augusto César Sandino (1895-1934), na Nicarágua, e o peruano Haya de La Torre ${ }^{26}$, além de intelectuais como José Vasconcelos Calderón e Amado Nervo no México, Gabriela Mistral no Chile, García Monge e Brenes Mesén na Costa Rica, entre tantos outros ${ }^{27}$.

Em 1922, realizou-se o I Congresso Teosófico Centroamericano, em conjunto com a Confederação de Centros Espiritistas de Centroamérica e México ${ }^{28}$. A crescente importância destes círculos de associações, clubes e lojas de correntes esotéricas e espiritualistas motivou a vinda do principal líder teosófico, Jiddu Krishnamurti, para um giro pela América Latina, em 1926. O sucesso do evento motivou uma segunda vinda, em 1935, quando a visita estendeu-se ao Brasil, Uruguai, Argentina, Chile, México e Guatemala. Sua visita, por sua vez, despertou um gigantesco interesse pelas espiritualidades orientais em diversos círculos intelectuais e literários latinoamericanos ${ }^{29}$.

\section{Teósofos e Rosacruzes na Colômbia}

A situação que nos interessa especificamente - a da Colômbia - reproduz em linhas gerais o que ocorre em quase toda a América Latina: há uma presença quase onipresente da Igreja Católica, tanto em nível demográfico ${ }^{30}$, quanto cultural e político $^{31}$. Na verdade, a despeito do caráter nitidamente laico das instituições republicanas, na maioria dos países latinoamericanos a Igreja Católica gozava, então, da

\footnotetext{
${ }^{22}$ V. Wunderich, Sandino, uma biografia politica (Managua: Nueva Nicaragua, 1995), 143.

${ }^{23}$ Deves e Rao, "Redes teosóficas", 137.

${ }^{24}$ Arnold Krum-Heller, o fundador da F.R.A., era seu médico pessoal.

${ }^{25}$ Expulso da sociedade teosófica local por ordenar o assassinato de membros do Partido Comunista (Casaús, "La creación de nuevos espacios públicos en Centroamérica", 307).

${ }^{26}$ Fundador da Aliança Popular Revolucionária Americana (APRA) e seu maior líder.

${ }^{27}$ Casaús, "La creación de nuevos espacios públicos en Centroamérica", 301.

${ }^{28}$ Casaús, "La creación de nuevos espacios públicos en Centroamérica", 306.

${ }^{29}$ Casaús, "La creación de nuevos espacios públicos en Centroamérica", 304.

${ }^{30}$ A não ser por um reduzido número de imigrantes dos países protestantes, a totalidade da população nativa figura dos censos oficiais como católica, mesmo nos grandes centros urbanos (Rodolfo Roux, $A$ Igreja na Colômbia e na Venezuela, em: Historia Liberationis: 500 anos de História da Igreja na América Latina, E. Dussel org. (São Paulo: Paulinas - CEHILA, 1992), 428.

${ }^{31}$ Patricia Londoño-Vega, Religion, Culture, and Society in Colombia Medellín and Antioquia: 18501930 (New York: Oxford University Press, 2002), 27-30. Frank Safford e Marco Palacios, Colombia: Fragmented Land, Divided Society (New York: Oxford University Press, 2002), 266.
} 
condição de religião oficial e, portanto, de uma proteção especial por parte do próprio Estado $^{32}$.

Arce Fustero destaca a Colômbia como exemplo de uma situação em que o projeto de construção de uma identidade nacional e republicana fracassa em consolidar seus próprios símbolos identitários, gerando uma situação ambígua em que a consciência coletiva republicana é dependente do simbolismo católico ${ }^{33}$, tomado como parte da modernidade e do mundo secularizado. Um esforço por parte de governos liberais em limitar o poder da Igreja, durante o chamado Radicalismo (1861-1880), levou a um processo muito específico de "romanização", em que a estrutura eclesial foi rapidamente centralizada e mobilizada para lutar contra o liberalismo ${ }^{34}$. Esse modelo de catolicismo tradicional, fortemente intransigente e avesso a mudanças, primeiro se afirmou internamente - praticamente eliminando os círculos católicos simpáticos à modernidade - e, em seguida, dedicou-se ao controle do aparelho estatal ${ }^{35}$.

Desse modo, a Igreja colombiana passou a exercer praticamente um controle direto sobre as instituições republicanas. Entre 1885 e 1930, o clero católico controlou importantes segmentos do Estado colombiano, durante sucessivos governos conservadores, de tal forma que o período chega a ser conhecido como "a república dos padres". ${ }^{36}$ O nível de ingerência da Igreja nos assuntos políticos do país e sua íntima aliança com os grupos políticos dominantes supera o que se observa no restante do continente $^{37}$. Neste sentido, merece destaque a atuação de instituições como a Accion Catolica General - liderada pelo monsenhor Gonzalez Arbelaez, claramente inspirada na Falange espanhola - ${ }^{38}$ e o Comitê de Defensa da La Fé Nacional, presidido pelo padre Eduardo Ospina ${ }^{39}$. A partir de 1948, em especial no governo de Laureano Gomez $(1950-53)^{40}$, a Igreja apoiou uma intensa perseguição estatal a outras denominações religiosas, principalmente contra os protestantes, sob o argumento de que a ruptura da

\footnotetext{
32 Gilson Ciarallo, "O tema da liberdade religiosa na política brasileira do século XIX: uma via para a compreensão da secularização da esfera política", Revista de Sociologia Política 19, no. 38 (2011): 85-99.

33 Gustavo Arce Fustero, Anticlericalismo, secularización y violencia: algunas pautas de historia comparada entre España y Colombia (1930-1948). Ana Greising e J. D. Vargas, Globalizacion y diversidad religiosa em Colombia (Bogotá: Univ. Nacional Colombia, 2005), 156.

34 William Quezada, La romanizacion de La Iglesia em el siglo XIX, proyecto globalizador del tradicionalismo católico. Greising e Vargas, Globalizacion y diversidad religiosa, 147.

${ }^{35}$ Desse modo, assistiu-se aqui a uma situação diversa da verificada no caso brasileiro, onde a partir do Regresso Conservador (1837), "o governo passou a adotar medidas com intuito de inibir a atuação político-partidária do clero", decisão esta orientada pela tradicional influência moral dos párocos sobre a população e seus envolvimentos constantes em movimentos sediciosos, tanto no período colonial, quanto na Regência. Italo Santirocchi, "Afastemos o Padre da Política! A despolitização do clero brasileiro durante o segundo Império", Mneme - revista de Humanidades 12, no. 29 (2011): 193.

${ }^{36}$ Londoño Vega, Religon, Culture, 31.

37 J. M. Roberts, "Algunas consideraciones globales sobre modernidad y modernización en el caso colombiano”, em Colombia: el despertar de la modernidad (Bogotá: Foro Nacional por Colombia, 1993), 16.

${ }^{38}$ Greising e Vargas, Globalizacion y diversidad religiosa, 169.

${ }^{39}$ Greising e Vargas, Globalizacion y diversidad religiosa, 219.

${ }^{40}$ Líder da ala mais radical do Partido Conservador, defensor intransigente do catolicismo (Carlos Prias. Gustavo Rojas Pinilla y el clero em Boyacá. Greising e Vargas, Globalizacion y diversidad religiosa, 199.
} 
unidade e da identidade católica do povo colombiano abririam espaço para o comunismo ${ }^{41}$.

Por conta disso, a constituição de um espaço reconhecido de pluralidade religiosa e liberdade de pensamento não só ocorre tardiamente, em comparação com seus vizinhos ${ }^{42}$, como permaneceu durante décadas ameaçado pelo clima de violência política que assolou o país ao longo do século $\mathrm{XX}^{43}$.

É nesse contexto de conflito aberto entre católicos e liberais, que a Sociedade Teosófica foi a pioneira entre as instituições esotéricas fundadas na Colômbia. A primeira loja foi fundada pelo pedagogo Ramon Martinez Rodrigues - um liberal convicto - que havia combatido na "Guerra dos Mil Dias"44, onde atingiu o posto de coronel e, mediante a derrota do movimento, teve que exilar-se na América Central. Como já vimos, as correntes liberais centroamericanas eram, então, fortemente influenciadas por correntes espiritualistas e teosóficas, nas quais militavam outros exilados colombianos, como o poeta Porfírio Barba Jacob (1883-1942) (5) $^{\text {, importante }}$ figura da imprensa teosófica centroamericana. Ramon foi, ainda, o editor da primeira publicação teosófica colombiana, a Revista Hermes ${ }^{46}$.

A chegada das instituições esotéricas, na Colômbia, coincide com um importante esforço liberal de secularização da sociedade colombiana:

A Secularização estava irresistivelmente invadindo a sociedade. A imprensa liberal começou a se recuperar após 1910. Sociedades teosóficas, lojas maçônicas, espiritualistas e rosacruzes, com seus ritos e periódicos, foram aparecendo em grande parte do país, mas principalmente nas cidades e espaços urbanos liberais. Até mesmo a imprensa conservadora, cada vez mais atenta aos gostos e inclinações de seus leitores, imperceptivelmente estava se tornando secularizada $^{47}$.

Conforme veremos, essas instituições disputaram espaço com a Igreja Católica no campo religioso colombiano. O poder do oponente comum fez com que, num

\footnotetext{
${ }^{41}$ Greising e Vargas, Globalizacion y diversidad religiosa, 14.

${ }^{42}$ A liberdade religiosa, na Colômbia, somente é reconhecida a partir da constituição de 1991. Ver, a respeito, Jorge Munevar. La libertad religiosa em Colombia. Greising e Vargas, Globalizacion y diversidad religiosa, 247-256.

${ }^{43}$ A. Aggio e M. Lahuerta orgs., Pensar o Século XX: problemas políticos e história nacional na América Latina (São Paulo: Ed. UNESP, 2003).

${ }^{44}$ Conflito que opôs liberais e conservadores, entre 1899 e 1902, e terminou com a vitória destes, além de servir de pretexto para uma intervenção norte-americana que resultou na independência do Panamá, em 1903. O conflito teria resultado em aproximadamente 100.000 vítimas e marcou profundamente o país; ele é o pano de fundo do romance Cem Anos de Solidão, de Gabriel García Marques.

${ }^{45}$ Conheceu a Sociedade Teosófica na Nicarágua, em 1909, e tornou-se então um entusiasta de suas ideias. Dez anos depois, atraído pela reorganização dos grupos liberais no país, regressou à Colômbia, onde fundou a Loja Arco Iris, em 1921, com o apoio do Centro Espírita Leon Denis, seguindo, nesse sentido, a aliança umbilical entre correntes teosóficas e espiritistas que se observa, no mesmo período, em toda América Central. Deves e Rao, "Redes teosóficas", 139.

${ }^{46}$ Corina Martinez Sanders, Cuarenta Años de Teosofía en Colombia (1920-1960) (Sociedad Teosófica, Sección Colombia, Data n/d.): disponivel em http://www.teosofiaencolombia.com/hriaencolombia.html

${ }^{47}$ Safford e Palacios, Colombia: Fragmented Land, 287.
} 
primeiro momento, esoteristas, espíritas e evangélicos se unissem para conquistar o direito de existência; mais tarde, à medida que esse espaço se consolida e começa a crescer, iniciaram-se as disputas e dissidências internas, mesmo entre as escolas esotéricas.

$\mathrm{Na}$ esteira dos teósofos, chegaram à Colômbia os rosacruzes. O médico alemão Arnold Krum-Heller (1876-1949) havia constituído na Cidade do México um importante círculo de iniciados, que incluía o célebre poeta Amado Nervo, e fundou, em 1927, sua própria escola esotérica: a Antiga Fraternidade Rosacruz (Fraternitas Rosicrucianum Antiqua - FRA). Sua prestigiosa posição em lojas maçônicas e o sucesso de suas obras logo o tornaram conhecido entre adeptos do ocultismo, o que permitiu um crescimento vertiginoso de sua instituição. Visitando a Colômbia, durante um giro internacional pela América do Sul, Krum-Heller assistiu à fundação da primeira loja colombiana, Aula Lucis Rasmussen ${ }^{48}$, em 27 de abril de 1928, na cidade de Bogotá, dirigida então pelo professor Israel Rojas Romero (1901-1985) ${ }^{49}$.

Em pouco tempo formaram-se quatro grupos de estudos, ou aulas lucis, na cidade de Bogotá, e a instituição logo se expandiu para as cidades vizinhas, como Honda e Girardot, e para o litoral, em Cartagena e Barranquilla. Em fevereiro de 1934, Israel passou a publicar a Revista Rosacruz ${ }^{50}$, um pequeno opúsculo, inicialmente quadrimestral, distribuído gratuitamente. Já, então, havia um total de nove grupos em funcionamento. $\mathrm{O}$ editorial da revista assim define a instituição:

A Fraternidade Rosa-Cruz é um movimento para a difusão de um ensinamento definido, lógico e continuado referente à origem, evolução e desenvolvimento futuro do mundo e do Homem, que demonstra por sua vez os aspectos Espirituais e Científicos. Não busca o proselitismo, senão o fazer dos ensinamentos cristãos um fator vivente na Terra, animando aos homens a permanecerem em suas igrejas, dando-lhes explicações que o Tempo tem obscurecido. E àqueles que têm cortado toda relação com as Igrejas, lhes oferece uma ancoragem temporária até o momento em que despertem em uma compreensão mais profunda do poder do aperfeiçoamento e da inefável beleza dos ensinamentos Filosóficos Cristãos ${ }^{51}$.

A Revista Rosacruz era, essencialmente, um veículo simultâneo de divulgação da nova instituição e de seu projeto cultural, buscando atingir dois tipos distintos de

\footnotetext{
${ }^{48} \mathrm{O}$ nome é uma homenagem a um personagem do livro Rosa-Cruz: novela de ocultismo iniciático, escrita por Krum-Heller em 1926.

49 Israel Rojas, Por los Senderos del Mundo (Bogotá: Editorial Minerva, 1973). Mario Grajales, El Legado de Israel Rojas Romero (Cali, 2010): disponível em http://pt.scribd.com/doc/44271332/ElLegado-de-Israel-Rojas

${ }^{50}$ A revista teve seu nome alterado para Revista Rosacruz de Oro, em 1940, e é normalmente conhecida exclusivamente por esse nome. Graças ao labor de uma associação cultural de esoteristas, La Comunidad de Alejandria, que patrocina um importante trabalho de resgate da memória do esoterismo latinoamericano, a revista foi digitalizada e está disponível hoje para consulta online em http://elarboldelashesperides.org/web/revistas/rosacruz-de-oro/

${ }^{51}$ Rojas, Revista Rosacruz 1 (1934): 1.
} 
público. O primeiro deles, constituído por pessoas que já estavam integradas a instituições de caráter espiritualista e teosófico. Seguindo a lógica de múltiplo pertencimento, comum a este meio, a Revista divulgava a FRA como um espaço complementar de aprendizado e prática espiritual. Além de trazer artigos de figuras amplamente aceitas nos meios esotéricos e espiritualistas - como Blavatsky e Eliphas Levi -, a Revista buscava expor sua própria doutrina rosacruz, divulgando autores como Max Heindel e o próprio Krum-Heller.

O segundo público, mais geral, pertencia ao novo ambiente cultural urbano, que se constituía rapidamente no país a partir da década de 1930, onde havia uma enorme curiosidade por descobertas científicas sobre o ser humano e informações de cunho cultural sobre religiosidade oriental ${ }^{52}$. Destacam-se, neste sentido, artigos sobre hipnotismo, forças mentais, ioga, as novidades da psicologia e, principalmente, longos artigos sobre o uso da medicina natural (cromoterapia, homeopatia, etc.), que permitem introduzir a temática que é fundamental para o esoterismo de então: a questão da regeneração moral e energética do ser humano, apresentando o rosacrucianismo como uma ciência da regeneração, além de divulgar os livros do próprio Israel Rojas sobre tais assuntos.

Esse novo ambiente cultural - que combina descobertas científicas, reinterpretações do passado e questionamentos ou demonstrações sobre o sobrenatural massifica-se rapidamente e movimenta figuras carismáticas do meio esotérico e espiritualista, que circulavam pelas grandes cidades colombianas, proferindo palestras e fazendo demonstrações públicas de seus conhecimentos. Além do próprio Krum-Heller - que proferiu uma palestra sobre o simbolismo ocultista das óperas alemãs, no Teatro de Bogotá, em 1928, podemos destacar a passagem do austríaco Maximo Neumayer, também em Bogotá, em 1930, a convite da FRA ${ }^{53}$, onde realizou demonstrações públicas de "curas psico-magnéticas". Da mesma forma, em agosto de 1938, houve a visita do então vice-presidente da Sociedade Teosófica, Jiddhu Jinarajadasa (18751953), fartamente noticiada pela imprensa local $^{54}$. A curiosidade pela mística do oriente também trouxe à Colômbia o guru javanês Bapak Subuh ${ }^{55}$.

\footnotetext{
${ }^{52}$ Carlos Mora atribui o crescimento do esoterismo/espiritualismo na nova sociedade urbana colombiana ao fato de não se basear em dogmas, mas atrair pelo ar fascinante e misterioso, além das promessas de saúde psicofísica e de novas experiências sensoriais. Sua fonte de autoridade não é um sacerdote, mas uma espécie de "expert-sábio-mestre" que lembra muito mais um conselheiro espiritual e um psiquiatra que um ministro de culto. Greising e Vargas, Globalizacion y diversidad religiosa, 97.

${ }_{53}$ Neumayer vivia no Brasil e pertencia ao ramo brasileiro da FRA; sua passagem pela Colômbia é descrita no livro Por los Senderos del Mundo, de Israel Rojas, e num artigo da Revista Rosa-Cruz de Oro de setembro de 1968.

${ }_{55}^{54}$ Revista Rosacruz 32 (1938): 512.

${ }^{55}$ Muhammad Subuh Sumohadiwidjojo (1901-1987), mais conhecido como Bapak Subuh, fundador da Spiritual Association of Susila Budhi Dharma, veio para o ocidente a convite de um discípulo de Gurdjieff, J. G. Bennett.
} 


\section{Magia Sexual: a trajetória do tantrismo, da Índia às selvas colombianas}

O tema da Magia Sexual é bastante complexo e polissêmico e sua compreensão é essencial para nosso trabalho, em virtude da centralidade que o tema ocupa na obra de Samael Aun Weor. A sexualidade mágica constitui um universo muito particular da magia moderna, e talvez seja um dos exemplos mais eloquentes das rupturas que permeiam o milieu esotérico, bem como da enorme quantidade de elementos conflitantes que se abrigam sob o mesmo guarda-chuva conceitual. É natural que as pessoas, ao ouvirem pela primeira vez falar sobre Magia Sexual, pensem em algum tipo de aberração ocultista, em alguma seita obscura, ou de alguma máscara através da qual a luxúria sensual se disfarce com um jargão místico. É significativo que, mesmo entre estudiosos do esoterismo, o tema da magia sexual tenha sido considerado alguma forma de desvio ou perversão, estranha ao seu corpo principal ${ }^{56}$.

Uma visão ascética e negativa da sexualidade é evidente tanto no pensamento platônico, quanto na moral judaica, as duas fontes primordiais do pensamento cristão; religião e sexo são vistos como antípodas; dedicar-se a um significa abrir mão do outro. Não parece casual o fato de que boa parte da iconografia de Pã, o deus grego da fertilidade, fora transformada pela imaginação cristã em viva representação do diabo, com seus chifres e patas característicos ${ }^{57}$. O esoterismo, normalmente, se baseia numa moral sexual cristã. Mesmo quando incorporam elementos das religiosidades orientais, a maior parte das doutrinas esotéricas possui, em relação ao sexo, uma postura muito semelhante, no sentido de que o desenvolvimento do espírito impõe, como regra, algum tipo de abstinência em relação aos desejos sexuais. Embora com motivações distintas, o celibato é dominante entre o clero budista e hinduista. Vamos observar essa mesma estética nas religiosidades esotéricas, como é ocaso da Igreja Liberal, ligada à Sociedade Teosófica, e nas nascentes igrejas gnósticas do final do século XIX e inicio do XX. Embora condenasse as motivações cristãs para o celibato ${ }^{58}$, a abstinência sexual era muito comum entre personalidades importantes da Teosofia, como a própria Blavatsky, o cel. Olcott e Krishnamurti.

Por outro lado, como aponta Mircea Eliade, a associação entre sexo e magia parece tão antiga quanto a humanidade. Eliade aponta a presença de orgias rituais e cultos da fertilidade como uma forma básica e generalizada de quase todas as culturas primitivas entre a Europa e a Índia. Para historiadores como Narendranath Bhattacharyya haveria uma ligação umbilical entre culturas matriarcais e formas

\footnotetext{
${ }^{56} \mathrm{O}$ próprio Antoine Faivre ignora solenemente a literature sobre o tema.

${ }^{57}$ Marcelo Campos. Magia Sexual e Cristianismo Primitivo: um estudo de Representações Sociais no Imaginário do Gnosticismo Samaeliano Contemporâneo. Alberto Moreira org., VII Congresso Internacional em Ciências da Religião: a Religião entre o Espetáculo e a Intimidade (Goiânia: PUC Goiás, 2014), 36.

${ }^{58}$ A questão do pecado. Nas culturas orientais, na forma de disciplina de autocontrole, também é exigido o celibato como pré-requisito para o desenvolvimento de poderes ocultos. Blavatsky, A Doutrina Secreta, vol. III - Antropogênese (São Paulo: Pensamento, 2014), 313.
} 
primitivas de magia sexual. Deusas como Cybele, Isis, Astarté e as deusas-mães indianas têm suas raízes em ritos sexuais que associam a abundancia de recursos naturais com a fertilidade humana ${ }^{59}$.

Desde os tempos das heresias gnósticas, na antiguidade tardia, passando pelos templários e cátaros na Idade Média, alguma forma de sexualidade ilícita sempre foi associada à prática de rituais secretos e "artes negras" $"$. Por outro lado, seja no hermetismo renascentista, na Cabala ou em Swedenbog, a união física entre homem e mulher sempre foi vista como uma metáfora terrestre da união entre os aspectos ativo e passivo da Divindade ${ }^{61}$. É apenas na obra do espiritualista americano Paschal Beverly Randolph, no entanto, que se vê pela primeira vez não apenas uma representação simbólica, mas a prática da união sexual como forma de se adquirir poder mágico que possa produzir efeitos reais no mundo físico.

Hugh Urban, apoiando-se na análise de Michel Foucault, chama a atenção para o contexto histórico em que se dissemina a Magia Sexual pelo ocidente; quando pensamos em sexualidade na Europa da segunda metade do século XIX, logo nos vem à mente a intensa repressão sexual da moral vitoriana. Para Foucault, no entanto, o quadro é muito mais complexo: ao contrário da forma como hoje imaginamos estes tempos, trata-se de um período em que irrompe com vigor o discurso sobre a sexualidade; há um interesse especial em categorizar e classificar o fenômeno, em especial as formas "desviantes" e transgressivas, como o homossexualismo e a masturbação.

É significativo que o interesse pela magia sexual surja nesse quadro de obsessão moderna pela sexualidade ${ }^{62}$. A magia sexual aflora num contexto de crescente interesse científico pelo sexo, numa tentativa de regular a sociedade através do conhecimento sobre a reprodução. Há também um novo interesse por formas "desviantes" e "não reprodutivas" de sexualidade, encaradas muitas vezes como ameaças a uma sociedade capitalista regrada e produtiva. A própria sexualidade como categoria analítica é uma invenção do século XIX, quando se observa uma intensa proliferação de esforços para categorizar, teorizar e classificar em termos médicos tudo que diz respeito ao sexo. Em autores como Freud e Wilhelm Reich, a essência da natureza humana é definida em termos estritamente sexuais ${ }^{63}$.

\footnotetext{
${ }^{59}$ Hugh Urban, Magia Sexualis: Sex, Magic and Liberation in the Modern West Esotericism (Berkeley: Univ. California Press, 2006), 22.

${ }^{60}$ No caso dos gnósticos, é famosa a acusação de Santo Irineu, de que praticavam rituais de espermofagia, crendo que o consumo dos fluidos seminais, onde residiriam as sementes da alma (psique), os conduziria à unidade espiritual. Urban, Magia Sexualis, 31.

61 “Embora em nenhuma delas haja menção explícita do intercurso sexual como técnica mágica, fornecem toda a base intelectual para a moderna Magia Sexual”. Urban, Magia Sexualis, 15.

${ }^{62}$ Foucault argumenta que a obsessão moderna com a sexualidade deriva do desencantamento do mundo; num mundo em que "Deus morreu", a sexualidade, sobretudo em suas formas transgressivas, torna-se um das poucas fontes de experiência intensa e libertadora, ultrapassando os limites da ordem social convencional. Urban, Magia Sexualis, 6.

${ }^{63}$ Reich considera que todo tipo de liberdade, seja espiritual, psicológica ou política depende da liberdade do instinto sexual. Urban, Magia Sexualis, 8-9.
} 
O pensamento de Foucault gira em torno das dinâmicas de afirmação do poder e das resistências que ela encontra, numa relação de interdependência mútua. A sexualidade é uma arena ativa desse processo, e a própria magia sexual revela uma contínua tensão entre um desejo de liberdade político-social e uma realidade de exploração do desejo sexual como instrumento de controle. ${ }^{64}$ Ao mesmo tempo, isso coincide com um intenso processo de assimilação de tradições recentemente descobertas pelo ocultismo ocidental, oriundas do Hinduismo e do Budismo.

O tema, como destacam alguns de seus estudiosos, representa uma janela privilegiada para visões críticas da inconstância das atitudes sociais em relação à sexualidade, autoridade religiosa e liberdade nos últimos duzentos anos:

Falar sobre magia sexual envolve muito mais do que a fantasia ocultista de manipular ou otimizar o orgasmo. Na verdade, ela oferece uma via de escape, ou de alivio, para tensões sociais, morais e políticas, oferecendo algumas perspectivas surpreendentes sobre nossa própria história cultural, para não mencionar a tensa relação entre sexualidade e espiritualidade na era moderna. Mas, talvez o mais importante, a literatura sobre magia sexual nos obriga a refletir autoconsciente e criticamente a respeito de nossas obsessões sobre sexo e liberdade numa sociedade capitalista ${ }^{65}$.

Nesse processo, a magia sexual descreve um curioso percurso em que se transforma, de uma prática medieval herege e subversiva, numa forma moderna de empoderamento pessoal e liberação social, em elemento amplamente aceito na cultura contemporânea e adaptado à lógica de mercado ${ }^{66}$. Essa trajetória revela que, a despeito de um discurso fortemente apoiado na noção de Prisca Theologia e de valorização de uma representação idealista do passado, a literatura sobre magia sexual que emerge a partir de meados do século XIX é intensivamente "moderna", expressando alguns dos temas mais importantes tipicamente associados à modernidade ocidental ${ }^{67}$, como a apologia da ciência objetiva e o valor da individualidade e da liberdade de escolha, constituindo uma "celebração do eu e uma sacralização da modernidade"68.

O caráter moderno da magia sexual pode ser percebido em quatro dimensões distintas. Primeiro, a literatura sobre o tema enfatiza o poder do individuo como a suprema força criativa do universo ${ }^{69}$. Segundo, tal como nas novas formas de Scientia Sexualis que surgem no século XIX, a magia sexual identifica o sexo como a mais

\footnotetext{
${ }^{64}$ Urban, Magia Sexualis, 10.

${ }^{65}$ Urban, Magia Sexualis, X.

${ }^{66}$ Urban, Magia Sexualis, 2-3.

67 “O que é peculiar na sociedades modernas não é o fato de condenarem o sexo a uma existencia sombria, mas o fato de dedicaram-se a falar sobre o mesmo ad infinitum, enquanto o exploram em segredo" (Foucault).

68 Paul Heelas, The New Age Movement: The Celebration of the Self and the Sacralization of Modernity (Oxford: Blackwell, 1996), 169.

${ }^{69}$ Nas palavras de Crowley: "cada individuo é o centro de seu próprio universo, e sua natureza determina seu próprio curso de ação" (citado em Jhon Symonds, The Confessions of Aleister Crowley: An Autohagiography (New York: Hill and Wang, 1969), 873.
} 
poderosa força da natureza humana, a chave para entender os mistérios de sua existência. Terceiro, ela reflete a ênfase moderna numa abordagem científica como a via mais adequada de investigação dos segredos da natureza e do homem, destacando seu caráter experimental. Finalmente, os defensores da magia sexual estão todos ligados, de uma forma ou de outra, a algum tipo de busca utópica por uma liberdade radical em todos os níveis - sexual, religioso e político ${ }^{70}$.

Há duas dinâmicas distintas na história da magia sexual ocidental. Numa delas, em que se destacam Theodor Reuss e Crowley, a magia sexual é fruto de uma releitura do tantrismo hindu. Numa outra, mais recente, a magia sexual faz parte de uma espécie de renascimento dos cultos europeus pré-cristãos, repousando num imaginário neopagão, onde se destaca Gerald Gardner (1884-1964); aqui o sexo torna-se um ritual que personifica as forças vivas da natureza ${ }^{71}$. Para os objetivos da discussão aqui proposta, interessa-nos particularmente a primeira dinâmica.

O primeiro autor a falar claramente sobre Magia Sexual no ocidente, o espiritualista Paschal Beverly Randolph (1825-1875), esteve em viagens pelo Oriente Médio, onde afirma ter aprendido suas técnicas, embora seja mais provável que as tenha elaborado a partir das obras de orientalistas que mencionam o assunto. Sua magia sexual consiste, essencialmente, em adotar posturas mentais que propiciem a assimilação de forças cósmicas durante o intercurso sexual, em especial no momento do orgasmo. ${ }^{72}$ Em seu sistema, ele considera particularmente importante que a mulher e o homem cheguem simultaneamente ao clímax. A despeito de insistir que sua técnica era restrita ao uso de casais devidamente constituídos e que a postura para a prática exigia a mais completa pureza de intenções - com sessões de magia sexual intercaladas com períodos de celibato que iam de 10 a 40 dias -, sua literatura foi taxada como "imoral" e lhe custou um breve período na cadeia, em $1872^{73}$.

$\mathrm{Na}$ virada do século, Theodor Reuss (1855-1923) constituiu a Ordo Templis Oriente (O.T.O.), uma mistura de maçonaria, rosacrucianismo e religiosidade oriental, especialmente o tantrismo. Suas práticas de magia sexual teriam sido aprendidas de Carl Kellner (1851-1905); sua descrição da técnica, carregada de termos velados, sugere a prática de espermofagia ${ }^{74}$. A magia sexual constitui o centro das práticas da OTO ${ }^{75}$ para Reuss e, sobretudo, para Crowley, o retorno da magia sexual constitui um rompimento com a moral sexualmente repressiva do cristianismo. O mago inglês Aleister Crowley (1875-1947) é, seguramente, a figura mais famosa do milieu da magia sexual. Urban o considera uma figura importante para entender a sociedade moderna como um todo, por três razões: primeiro, sua rejeição radical da moralidade vitoriana e sua ênfase no sexo como fonte suprema da magia constituem um reflexo de sua era e

\footnotetext{
${ }^{70}$ Urban, Magia Sexualis, 7.

${ }^{71}$ Urban, Magia Sexualis, 18.

${ }^{72}$ Paschal B. Randolph, Magia Sexualis (Paris: Robert Telin, 1931), 10-20.

${ }^{73}$ Urban, Magia Sexualis, 70-71.

${ }^{74}$ Consumo ritualístico de secreções sexuais. Francis King, The Magical World of Aleister Crowley (London: Weidenfeld \& Nicolson, 1977), 79.

${ }^{75}$ Urban, Magia Sexualis, 100.
} 
das atitudes em relação ao sexo na Inglaterra vitoriana tardia ${ }^{76}$. Segundo, ele constitui uma figura chave na transmissão de tradições orientais para o ocidente, em especial do Tantra. Terceiro, em grande parte por conta da incorporação dos elementos orientais, Crowley se torna uma das mais influentes figuras do renascimento mágico e da religiosidade alternativa novaerista ${ }^{77}$.

Urban analisa Crowley a partir do conceito de "transgressão", de Georges Bataille, segundo qual, o discurso de Crowley sobre sexualidade buscaria, deliberadamente, violar os tabus mais sagrados de sua época; seus atos deliberados de transgressão pretendiam romper as fronteiras da sociedade ocidental e abrir caminho para uma nova era de liberdade ${ }^{78}$. Foucault analisa a transgressão de Bataille dentro de um quadro em que a ascensão da sexualidade tem relação com a "morte de Deus" e o declínio das tradicionais crenças religiosas. Para Bataille, o poder do sexo reside numa relação dialética entre tabu e transgressão, mediante a qual se constrói, sistematicamente, um conjunto de regras úteis para um primeiro momento, mas que em seguida precisam ser superadas, por se tornarem uma forma de barreira para a evolução. "A proibição está lá para ser violada", diz ele; é a experiência de ultrapassagem dos limites que traz a sensação de êxtase, de continuidade e comunhão com o Absoluto ${ }^{79}$.

Esse tantrismo que é assimilado pelos ocultistas europeus nada mais é que uma releitura ocidental, carregada de juízo de valores de missionários e orientalistas, em plena era de expansão imperialista pelo extremo oriente. A começar pela interpretação de que o tantra gira em torno do sexo. A palavra tantra vem do sânscrito tan, que pode ser traduzido como tecer, esticar ou propagar; o termo tem usos variados ao longo da história hindu, indicando deste um tear até um sistema filosófico, um exército, uma droga ou um remédio. O tantra, em seu contexto asiático, gira não em torno do sexo, mas da energia criadora que impregna todo o cosmos e constitui o principio da vida, shakti; as técnicas sexuais, que não se encontram em todas as linhas do Tantra, compõem um segmento das técnicas voltadas ao despertar e canalização desta energia. No Kulanarva Tantra, por exemplo, as técnicas são descritas como exercícios secretos que só devem ser ensinados a adeptos já experimentados na doutrina e de grande rigor moral. A ideia central gira em torno de assimilar os diferentes tipos de energia presentes na natureza, conhecidos como Tattwas $^{80}$; isso levaria a um processo de ritualização da própria vida, na medida em que é necessário adotar uma postura adequada para assimilar o tattwa do ar, no momento da inspiração, o tattwa dos alimentos, no ato de

\footnotetext{
${ }^{76}$ Como destaca Foucault, a cultura pós-vitoriana vai ser marcada por uma intensa reação contra a hipocrisia moral; em escirtores como D. H. Lawrence, Oscar Wilde e Havelock Ellis vemos uma apologia da liberdade erótica, incluindo práticas "desviantes" como a masturbação e o homossexualismo. Urban, Magia Sexualis, 111.

${ }^{77}$ Urban, Magia Sexualis, 100.

${ }^{78}$ Apenas para citar um exemplo, sua Missa Gnóstica incluía o consumo ritualístico de sangue menstrual. Urban, Magia Sexualis, 121.

${ }^{79}$ Urban, Magia Sexualis, 130.

${ }^{80}$ Marcelo Campos, "Magia Sexual e Cristianismo Primitivo: um estudo de Representações Sociais no Imaginário do Gnosticismo Samaeliano Contemporâneo", em VII Congresso Internacional em Ciências da Religião, 35.
} 
comer, etc.. Desse modo, o ato sexual também envolveria a assimilação de tattwas, sendo esse o propósito básico dos exercícios sexuais. No Ritual Pancatattwa, por exemplo, o adepto consome de forma ritualística os cinco principais tattwas através do consumo ritual de frutas, pão, vinho e peixe, finalizando com o ato sexual ${ }^{81}$.

O tantrismo está presente no hinduísmo, no budismo e no taoismo; constitui um sistema complexo com diversas linhas que têm ideias e práticas conflitantes entre si. Aqui nos interessa, em especial, as disputas de significados em torno do orgasmo, que serão transportadas para o ocidente.

O tantrismo, sobretudo na forma como se dissemina no budismo e no taoismo, valoriza sobremaneira as técnicas que permitem a retenção do sêmen e sua "sublimação"; tal forma é conhecida como "via seca", e normalmente constitui a base do Kundalini Yoga. Presente no milieu rosacruciano e gnóstico do final do século XIX, foi adotada por Arnold Krum-Heller, que a incorporou a seu arsenal de exercícios para melhorar a saúde física. Contudo, tal prática só viria a assumir centralidade na doutrina de Samael, onde constitui o único caminho que conduz ao despertar da consciência.

Ainda nesse contexto médico, a técnica foi popularizada pela obstetra norteamericana Alice Bunker Stockham (1833-1912). Com os nomes de "método Karezza" ou Coitus Reservatus, foi ensinada como método contraceptivo e defendida como uma prática que estimulava a igualdade de gênero ${ }^{82}$. Adotada, com diversas variantes, em comunidades espiritualistas norte-americanas, como a Sociedade Oneida, exerceu enorme influência sobre o imaginário de liberdade sexual da contracultura dos anos 60 .

O chamado tantrismo de mão esquerda, porém, ensina diferentes processos de perda seminal e posterior reabsorção, seja por meio de consumo ritual (espermofagia) ou de técnicas iogues que permitem sua reinserção pela uretra, como no caso do Vamachara Tantra, do Ceilão, com a qual Crowley teve contato quando viajou pela India, entre 1901-1902 ${ }^{83}$.

Estas práticas são centrais na doutrina Crowleyana, conhecida como "Thelema"; seus praticantes se autodenominam "thelemitas", sendo também conhecidos como "espermo-gnósticos" e "hiperbóreos" ${ }^{84}$. Estão presentes na O.T.O, na Astrum Argentum (A.A.) e numa miríade de grupos que compõem a constelação crowleyana.

É justamente a oposição de Samael à concepção crowleyana de magia sexual que vai marcar o nascimento do Movimento Gnóstico. Como vimos, há dois elementos fundamentais que opõem a magia sexual crowleyana ou thelemita à sua equivalente samaeliana. O primeiro é de ordem doutrinária: Crowley utiliza a magia sexual como um aríete para se opor à moral sexual cristã, enquanto Samael se esforça para conciliar ambos. A segunda é de ordem técnica e representa duas concepções opostas de

\footnotetext{
${ }^{81}$ Urban, Magia Sexualis, 407.

82 Arthur Versluis, The Secret History of Western Sexual Mysticism: Sacred Practices and Spiritual Marriage (Rochester: Bear \& Company, 2008), 114. Ver também Alice Stockham, Karezza Ethics of Marriage (Whitefish: Kessinger Publishing, 2004).

${ }^{83}$ Versluis, The Secret, 125.

${ }^{84}$ Ver, a respeito, Peter-R Koenig, Ein leben für die rose (München: ARW, 1995).
} 
fisiologia oculta em relação ao despertar do Kundalini: no modelo de Crowley, a prática sexual chega ao orgasmo e os fluídos seminais são consumidos ritualisticamente (espermofagia), enquanto no sistema samaeliano o orgasmo é substituído por exercícios respiratórios que visam "sublimar" as secreções seminais.

Um cidadão cubano, que declarava ser o monge tibetano Omar Cherenzi, associou-se ao líder colombiano da F.R.A., Israel Rojas, e veio para a Colômbia no final de 1938, onde fundou a Universidade Espiritual. Nessa nova instituição Cherenzi passou a oferecer um disputado curso iniciático para conferir um grau iniciático intitulado Anagarikha, onde ensinava alguns exercícios crowleyanos. Quando rompeu com Rojas, no início de 1939, boa parte dos grupos rosacruzes filiaram-se à nova escola. Samael, que também havia rompido com Israel Rojas, funda uma nova escola esotérica, o Movimento Gnóstico, para denunciar os exercícios de Cherenzi e fazer apologia de sua concepção de magia sexual.

\section{Samael e Gurdjieff}

Finalizando nossas reflexões sobre Samael, gostaríamos de abordar brevemente um importante elemento de suas dinâmicas doutrinárias, que tem importante relação com toda a dinâmica estrutural de suas instituições: a apropriação de elementos do "Quarto Caminho", a doutrina esotérica da dupla de esoteristas russos Gurdjieff e Ouspensky.

Gurdjieff notabilizou-se por ensinar uma doutrina esotérica fortemente apoiada em explicações psicológicas, que Ouspensky intitula de "Psicologia Esotérica". Segundo este modelo, o desenvolvimento das capacidades mágicas do ser humano depende única e exclusivamente do desenvolvimento de sua capacidade de ser consciente; para ele, o ser humano comum vive num estado permanente de "sono da consciência", sendo que o despertar desta consciência somente é possível através de um elaborado e exigente programa de exercícios, que constituem o chamado "Quarto Caminho" ${ }^{85}$.

Samael não faz segredo da adoção de concepções gurdjieffianas, embora não se preocupe em lhe conceder os créditos pela totalidade de incorporações que opera. Também é importante frisar que Samael opera uma apropriação seletiva, a partir da qual elabora um modelo bastante original, distinto das concepções do próprio Gurjieff. Samael, por sinal, é prolífico em apontar falhas no pensamento gurdjieffiano. Apenas para citar um exemplo, o exercício gurdjieffiano de Auto-Observação, que em seu modelo original é exclusivamente uma técnica de educação da atenção, na gnose samaeliana vai se tornar a primeira parte de um exercício profundamente místico de "eliminação do ego", mediante o qual o discípulo interage com uma reinterpretação do

\footnotetext{
${ }^{85}$ Que seria, essencialmente, uma combinação harmoniosa dos três caminhos tradicionais de educação da consciência: o caminho do faquir (domínio do corpo físico), do místico (domínio das emoções) e do iogue (domínio do intelecto).
} 
culto mariano, tão caro e familiar ao catolicismo popular latinoamericano, evocando a figura da "Mãe Divina".

As aproximações entre Gurdjieff e Samael não escaparam à observação dos pesquisadores que se debruçaram sobre a obra deste último e as atividades de suas instituições. O sociólogo italiano Pierluigi Zoccatelli , embora reconhecendo outras importantes contribuições ao pensamento de Samael - como a Gnose de Krum-Heller, o tantrismo, a Teosofia e a Thelema, de Crowley, que levam inclusive Samael a se definir como um "mestre da Síntese" - ${ }^{86}$, chama a atenção para o fato de que importantes elementos da doutrina gurdjieffiana estruturam, em grande medida, o coração da doutrina de Samael; particularmente, refere-se aos "Três Fatores de Revolução da Consciência" $^{87}$. Outra referência obrigatória é a tese de doutorado do antropólogo espanhol José Alvaro Lopez Bellas ${ }^{88}$. Seu trabalho, publicado em 2008 em dois volumes que totalizam 1.532 páginas, é, até o momento, o trabalho mais sólido sobre as instituições gnósticas e as obras de Samael e seu principal discípulo, Joaquim Amortegui Balvuena (Rabolu). Lopez Bellas também traz um levantamento consistente da influência das ideias de Gurdjieff na obra de Samael, analisando a percepção de tal influência entre seus seguidores ${ }^{89}$.

A antropóloga colombiana Carolina María Tamayo Jaramillo, orientada pelo Professor Johann F. W. Hasler, conduziu um trabalho etnográfico de observação participante realizado junto à Igreja Gnóstica da Colômbia, em Medellin ${ }^{90}$. Jaramillo se propõe, entre outras questões, a identificar os autores que influenciaram o pensamento de Samael, apontando como principais referências as figuras de Blavatsky, Krum-Heller e Gurdjieff, acompanhando, em linhas gerais, a avaliação de Zoccatelli ${ }^{91}$.

Em resumo, a influência de Gurdjieff sobre a obra de Samael é reconhecida de forma unânime entre os principais pesquisadores do tema, dentro do próprio milieu gnóstico e mesmo entre seus opositores, variando o grau de influência atribuído a essa influência. O que a maioria deles ignora, no entanto, é que Samael desconhece completamente as ideias de Gurdjieff no início de sua pregação pública; que seu interesse pelo esoterista russo somente se torna evidente após sua viagem ao México, em 1955. Esse interesse é visível de forma crescente ao longo das obras que escreveu na década de 1960, tornando-se evidente que Samael se baseou na "psicologia esotérica"

\footnotetext{
${ }^{86}$ Ingo Wulfhorst, "Movimento Gnóstico Cristão Universal do Brasil na Nova Ordem: um grupo da Nova Era", Estudos Teológicos 2, no. 35 (1995): 188.

${ }^{87}$ Pierluigi Zoccatelli, Sexual Magic and Gnosis in Colombia: tracing the influence of G.I. Gurdjieff on Samael Aun Weor, em Occultism in a Global Perspective, Henrik Bogdan ed. (Bristol: Acumen, 2013), $142-144$.

88 Lopez Bellas, Un estudio de antropología social de las organizaciones, el caso del MGCU (Movimiento Gnóstico Cristiano Universal) (Santiago de Compostela: Univers. Santiago, Servizo de Publicacións e Intercambio Científico, 2008).

${ }^{89}$ Lopez Bellas, Un estúdio, 230-236 e 268-273.

${ }^{90}$ Jaramillo, Gnosce Te Ipsum: uma analisis antropologico de la Iglesia Cristiana Universal de Colômbia desde la perspectiva de la Esoterologia (Medellin: Universidad de Antioquia, 2012).

${ }^{91}$ Jaramillo, Gnosce Te Ipsum, 85.
} 
de Gurdjieff/Ouspensky para propor sua "psicologia revolucionária", tema dominante de suas obras da década de $1970^{92}$.

Outra dinâmica histórica ignorada pelos pesquisadores e até mesmo pela grande maioria de seus seguidores, nas últimas décadas, é que algumas de suas principais obras - como é o caso de seu livro inaugural, O Matrimonio Perfeito, escrito em 1950 - foram posteriormente reescritas para incorporar as novas aquisições de sua doutrina, em especial os elementos gurdjieffianos. No caso do Matrimônio Perfeito, ele passou por duas revisões, entre 1966 e 1968, e a versão de 1950 deixou de ser reeditada, caindo no esquecimento.

A progressiva assimilação de noções do "Quarto Caminho" de Gurdjieff, por parte de Samael, marca um processo em que sua doutrina se desloca de uma posição inicial, em que predominam um elaborado ritualismo rosacruz combinado com ideias teosóficas, para outra, em que o centro doutrinário é dado por uma psicologia revolucionária de forte acento gurdjieffiano. Essa trajetória não ocorre de forma pacífica, e encontra resistência por parte de alguns de seus primeiros discípulos, oriundos em sua maioria do milieu rosacruz, com o qual permanecem fortemente identificados. É emblemático, por exemplo, que o segundo expoente do Movimento Gnóstico colombiano, Julio Medina Vizcaíno, fez objeções ao primeiro esforço empreendido por Samael de reescrever o livro O Matrimônio Perfeito, tendo recebido uma severa admoestação:

Situe-se no presente. Estamos transmitindo uma mensagem, e quando escrevi O MATRIMONIO PERFEITO estávamos no começo da mensagem. Agora A MENSAGEM ESTÁ MUITO AVANÇADA. O GRANDE BUDA Gargha Kuichines (Julio Medina) não pode ficar no passado. Tu deves viver de instante em instante, sempre no presente ${ }^{93}$.

Essa questão não é uma mera curiosidade; ela ajuda a entender, em grande medida, diversas dinâmicas que conduziram a uma intensa fragmentação das instituições gnósticas após o falecimento do seu fundador, em 1977. Em seus últimos meses de vida, ciente da animosidade crescente entre seus discípulos a respeito do papel que desempenhavam na doutrina gnóstica o ritualismo mágico e o trabalho psicológico, Samael fez um defesa apaixonada da complementaridade natural que haveria entre o Templo (o ritualismo mágico) e a Escola (o trabalho de psicologia esotérica), dentro da Gnose $^{94}$.

Com sua morte, porém, seus principais discípulos e familiares entraram em oposição aberta; a fragmentação daí decorrente pode ser dividida em três grandes

\footnotetext{
92 Ver, a respeito, minha hipótese de "transição doutrinária", descrita com detalhes em: Campos, "Esoterismo, Modernidade e Secularização: a Gnose de Samael Aun Weor" (Dissertação de Mestrado em Ciências da Religião pela PUC Campinas, 2015).

${ }_{93}$ Carta de Samael a Julio Medina, emitida no México, de 17/03/1961 (Acervo Linaje Gnóstico).

${ }^{94}$ Samael Aun Weor, Constituicion Organica de La Iglesia Gnostica Cristiana Universal y Reforma a los Estatutos Del Movimiento Gnóstico Cristiano Universal (México: MGCU, 1977), 10.
} 
grupos opostos. O primeiro, o "Templo", as igrejas gnósticas, voltadas resolutamente em direção ao ritualismo; seu líder mais evidente é o próprio Júlio Medina. O segundo, a "Escola", abre mão do ritualismo e intensifica o processo de psicologização da doutrina; seu expoente mais visível é a Nova Ordem gnóstica fundada por Joaquim Amortegui Balvuena. Um terceiro grupo lutou para manter a complementaridade Templo/Escola; aqui se destacam o Instituto Gnóstico de Antropologia fundado pela esposa de Samael, Arnolda Garro de Gomez, e a Associação Gnóstica de Estudos Antropológicos (AGEACAC), controlada então por sua filha, Hypatia Gomez.

\section{Conclusão}

Ao nos debruçarmos sobre os contextos históricos relacionados com o nascimento do Movimento Gnóstico na Colômbia procuramos oferecer subsídios para a compreensão das dinâmicas de chegada e disseminação do esoterismo ocidental à América Latina, essa "periferia" do ocidente, como a define Deves Valdes ${ }^{95}$, um dos pioneiros no estudo sobre o papel das novas espiritualidades esotéricas e orientalistas na história cultural do subcontinente. Ocorrendo num período mais tardio, em relação ao Velho Continente, a presença esotérica em terras latinoamericanas reforça o adesismo do "mago" a um projeto iluminista ${ }^{96}$ : as lojas esotéricas se disseminam principalmente entre as forças sociais então empenhadas na construção de uma sociedade secularizada; seu principal lócus de ação são os espaços urbanos cosmopolitas; o templo ocultista constrói escolas; seus jornais são espaços de disseminação do pensamento científico e racionalista; seus adeptos se engajam intensamente na política regional e a disseminação de seus valores contribui para o esforço de construção da identidade nacional.

Longe de ser um ator passivo deste processo, o "mago" latinoamericano - aqui representado pela figura emblemática de Samel Aun Weor - incorpora ao panteão europeu-oriental as diferentes formas de religiosidades endógenas, a partir de um processo de intensa circularidade cultural, que origina novas formas doutrinárias e novas práticas dotadas de capacidade para atender demandas existenciais da cidade e do campo, dos letrados e das pessoas simples. O rosacrucianismo que chegou à Colômbia era dominado pelo ritual mágico; transfigurado na gnose de Samael, a nova magia foi dominada pela união entre masculino e feminino; o corpo, outrora tabu, tornou-se a via de acesso ao espírito e, numa espécie de caminho de volta às suas terras de origem, num verdadeiro "efeito bumerangue", essa releitura latinoamericana atravessou o oceano e

\footnotetext{
${ }^{95}$ Valdes, El pensamiento latinoamericano em el siglo $X X$.

${ }^{96}$ Em relação a essa questão da modernidade, um erro muito comum é considerar exclusivamente a postura êmica; esoteristas, normalmente, não se identificam com a modernidade; são críticos ferrenhos de questões estruturais da modernidade; a odeiam, a demonizam. Mas isso não muda em nada o fato de que se apropriam, talvez até de forma inconsciente, de quase tudo que é importante na estética e no discurso moderno: buscam legitimar sua doutrina apoiando-se na ciência, ou mesmo definindo sua doutrina como ciência; suas instituições atendem por títulos modernos como "escolas", "associações", "movimentos", oferecendo cursos modelados a partir das formas laicas de disseminar conhecimento e estruturando suas organizações a partir de uma lógica de racionalidade e eficiência.
} 
produziu uma nova revolução nas espiritualidades europeias, cujos aspectos e implicações estão por merecer um tratamento mais detalhado.

Tal processo de assimilação da modernidade e de relação reversiva entre cultura moderna e esoterismo, ocorre numa arena carregada de tensões e conflitos que precisam ser analisados à luz de seus contextos históricos específicos. A trajetória de Samael constitui um bom exemplo dessas tensões. Nos seus anos iniciais de pregação pública, em plena crise das instituições colombianas e de guerra civil, seu discurso era claramente anti-moderno, milenarista e utópico; Samael deixa a cidade e busca refúgio na montanha. No momento seguinte, já no México, o mesmo Samael pode ser encontrado em pleno momento de efervescência política e cultural, transfigurado agora em político, antropólogo e psicólogo, defendendo sua doutrina com as novidades da física atômica e da medicina.

Essas idas e vindas são pragmáticas; como dissemos antes, a apropriação é seletiva e um distanciamento crítico em relação à modernidade é importante para se propor como alternativa às suas contradições. Como destaca Touraine, o mesmo século $\mathrm{XX}$, que assistiu ao triunfo da técnica e da ciência, foi dominado intelectualmente pelo discurso antimodernista ${ }^{97}$.

\section{Fontes}

"Correspondência de Samael Aun Weor e Julio Medina Vizcaino", entre 1953 a 1976, in: Acervo Linaje Gnóstico, reunida por Augusta Renowitzky e Faustino Camargo. Disponível em http://www.linajegnostico.org/cartasSAW.htm

Revista Rosacruz. Publicação da Antiga Fraternidade Rosacruz, a partir de abril de 1934, em Bogotá, dirigida por Israel Rojas. Acervo disponibilizado pela associação esotérica La Comunidad de Alejandria, que realiza um importante trabalho de resgate e preservação da memória do esoterismo latinoamericano. Disponível em http://elarboldelashesperides.org/web/revistas/rosacruz-de-oro/

\section{Bibliografia}

Arce Fustero, Gustavo. “Anticlericalismo, Secularizacion y Violencia: algunas pautas de historia comparada entre España y Colombia (1930-1948)". Em Globalizacion y Diversidad Religiosa em Colombia. Greising, Ana Vargas e J. D. Bogotá: Univ. Nacional Colombia, 2005.

Berger, Peter. O Dossel Sagrado. São Paulo: Paulinas, 1985.

Bubello, Chaves, Junior eds. Estudios sobre La Historia del Esoterismo Occidental en America Latina: enfoques, aportes, problemas y debates. No prelo.

Campos, M. L. "Magia Sexual e Cristianismo Primitivo: um estudo de Representações Sociais no Imaginário do Gnosticismo Samaeliano Contemporâneo. Em VII

\footnotetext{
${ }^{97}$ Alain Touraine, Crítica da Modernidade (Petrópolis: Vozes, 2009), 13.
} 
Congresso Internacional em Ciências da Religião: a Religião entre o Espetáculo e a Intimidade. Alberto Moreira org. Goiânia: PUC Goiás, 2014. Disponível em http://www.pucgoias.edu.br/w4567ucg/eventos/Congresso_Ciencias_Religiao/V _Congresso_Ciencias_Religiao/ArquivosUpload/1/file/AnaisGT20.pdf

Campos, M. "Esoterismo, Modernidade e Secularização: a Gnose de Samael Aun Weor”. Dissertação de Mestrado em Ciências da Religião pela PUC Campinas, 2015. Disponível em http://www.bibliotecadigital.puccampinas.edu.br/tde busca/arquivo.php?codArquivo=989

Casaús, Marta Elena. "La creación de nuevos espacios públicos en Centroamérica a principios del siglo XX: La influencia de redes teosóficas en la opinión pública centroamericana. Revista Universum 17 (2002): 297-332.

Ciarallo, Gilson. "O tema da liberdade religiosa na política brasileira do século XIX: uma via para a compreensão da secularização da esfera política". Revista de Sociologia Política 19, no. 38 (2011).

Figueroa, Helwar H. "Cambio de Enemigos: de Liberales a Comunistas". Em Globalizacion y Diversidad Religiosa em Colombia. Greising, Ana Vargas e J. D. Bogotá: Univ. Nacional Colombia, 2005.

Girgois, H. El Oculto entre los aborígenes de La America Del Sud. Buenos Aires: editor $\mathrm{n} / \mathrm{d}, 1901$.

Goodrick-clarke, Nicholas. The Western Esoteric Tradition: a historical introduction. Oxford: Oxford University Press, 2008.

Grajaels, Mario. El Legado de Israel Rojas Romero. Cali: 2010. Disponível em http://pt.scribd.com/doc/44271332/El-Legado-de-Israel-Rojas

Greising, Ana. Globalizacion y diversidad religiosa em Colombia. Bogotá: Univ. Nacional da Colombia, 2005.

Guerra, Lempiére. Los espacios públicos em Iberoamérica. Ambiguidades y problemas. Siglos XVIII e XIX. México: CEMCA/FCE, 1998.

Heelas, Paul. The New Age Movement: The Celebration of the Self and the Sacralization of Modernity. Oxford: Blackwell, 1996.

Introvigne, Massimo. Il Ritorno dell Gnosticismo. Varese: SugarCo., 1993.

Jaramillo, C. M. Gnosce Te Ipsum: uma analisis antropologico de la Iglesia Cristiana Universal de Colombia desde la perspectiva de la Esoterologia. Medellín: Universidad de Antioquia, 2012.

King, Francis. The Magical World of Aleister Crowley. Londons: Weidenfeld \& Nicolson, 1977.

Koenig, Peter-R. Ein leben für die rose. München: ARW, 1995.

Londoño-Vega, Patricia. Religion, Culture, and Society in Colombia Medellín and Antioqua: 1850-1930. New York: Oxford University Press, 2002.

López Bellas. Un estudio de antropología social de las organizaciones, el caso del MGCU (Movimiento Gnóstico Cristiano Universal). Santiago de Compostela: Univers. Santiago, Servizo de Publicacións e Intercambio Científico, 2008. 
Martínez Sanders, Corina. Cuarenta Años de Teosofía en Colombia (1920-1960). Sociedade Teosófica, Sección Colombia, data n/d. Disponível em http://www.teosofiaencolombia.com/hriaencolombia.html

Prias, Carlos. "Gustavo Rojas Pinilla y el clero em Boyacá". Em Globalizacion y Diversidad Religiosa em Colombia. Greising, Ana Vargas e J. D. Bogotá: Univ. Nacional Colombia, 2005.

Quezada, William. "La romanizacion de La Iglesia em el siglo XIX, proyecto globalizador del tradicionalismo católico”. Em Globalizacion y Diversidad Religiosa em Colombia. Greising, Ana Vargas e J. D. Bogotá: Univ. Nacional Colombia, 2005.

Randolph, Paschal Beverly. Magia Sexualis. Paris: Robert Telin, 1931.

Roberts, J. M. "Algunas consideraciones globales sobre modernidad y modernización en el caso colombiano". Em Colombia: el despertar de la modernidad. Bogotá: Foro Nacional por Colombia, 1993.

Romero, José Luis. As cidades e as idéias. Rio de Janeiro: Ed. UFRJ, 2004.

Roux, Rodolfo. A Igreja na Colômbia e na Venezuela. Em Historia Liberationis: 500 anos de História da Igreja na América Latina. E. Dussel coord. São Paulo: Paulinas - CEHILA, 1992.

Safford, Frank e Marco Palacios. Colombia: Fragmented Land, Divided Society. New York, Oxford University Press, 2002.

Santirocchi, Ítalo D. "Afastemos o Padre da Política! A despolitização do clero brasileiro durante o segundo Império". Mneme - Revista de Humanidades 12, no. 29 (2011).

Tirado, Armais L. Nuestra historia en Puerto Rico. Data n/d. Disponível em http://sociedadteosoficapr.org/histo pr.htm

Touriane, Alain. Crítica da Modernidade. Petrópolis: Vozes, 2009.

Trillo, Carlos. Recuentos Y Revalorizaciones al Mensage del Ariel de Rodó Cién Años Despues. Mexicali: UABC, 2000.

Tsadhe, H. S. Krum-Heller, El Rosa Cruz. Fraternitas Rosicruciana Antiqua de Venezuela, ano $\mathrm{n} / \mathrm{d}$.

Urban, Hugh B. Magia Sexualis: Sex, Magic and Liberation in the Modern West Esotericism. Berkeley: Univ. California Press, 2006.

Uribe, Otoniel E. "La difusión de la herejía o la siembra de la buena semilla: en el camino hacia la modernidad religiosa". Em Globalizacion y Diversidad Religiosa em Colombia. Greising, Ana Vargas e J. D. Bogotá: Univ. Nacional Colombia, 2005.

Valdes, Deves e Melgar Rao. "Redes teosóficas y pensadores (políticos) latinoamericanos 1910-1930". Cuadernos Americanos 78 (1999).

Valdes, Deves. El pensamiento latinoamericano em el siglo XX, entre La modernizacion y La identidad. Del Ariel de Rodó a La CEPAL (1900-1950). Buenos Aires: Biblos, 2000. 
Vallejo, Victor H. Passado, Presente y Futuro de la Francmasoneria. 2001. Disponivel em

http://www.astroescuela.com/logiarmonia39/contenido/documentos/politano/pas ado presente.htm

Versluis, Arthur. The Secret History of Western Sexual Mysticism: Sacred Practices and Spiritual Marriage. Rochester: Bear \& Company, 2008.

Weor, Samael. Constituicion Organica de La Iglesia Gnostica Cristiana Universal y Reforma a lós Estatutos Del Movimiento Gnóstico Cristiano Universal. México: MGCU, $1977 . \quad$ Disponível em http://pt.slideshare.net/PatriarcadoDeLaGnosisUniv/constitucion-organica-copia

Wulfhorst, Ingo. "Movimento Gnóstico Cristão Universal do Brasil na Nova Ordem: um grupo da Nova Era". Estudos Teológicos 2, no. 35 (1995): 186-210.

Wunderich, V. Sandino, uma biografia política. Managua: Nueva Nicaragua, 1995.

Yates, Frances. Giordano Bruno e a Tradição Hermética. São Paulo: Circulo do Livro, 1991.

Zocatelli, Pierluigi. "Sexual Magic and Gnosis in Colombia: tracing the influence of G.I. Gurdjieff on Samael Aun Weor". Em Occultism in a Global Perspective. Henrik Bogdan ed. Bristol: Acumen, 2013. 